\title{
HYDROLOGIC ANALYSIS OF SURYANAGAR WATERSHEDS USING IDF CURVES AND RUNOFF MODELS
}

\author{
M. Inayathulla ${ }^{1}$, Y A Narayana Swamy ${ }^{2}$, Chalapathi $K^{3}$, Shashishankar. $\mathbf{A}^{4}$ \\ ${ }^{I}$ Prof. Civil Engineering Department, U.V.C.E, Bangalore University, Bangalore, India \\ ${ }^{2}$ Research Scholar, Civil Engineering Department, SET-Jain University, Bangalore \\ ${ }^{3}$ Research Scholar, Civil Engineering Department, U.V.C.E, Bangalore University, Bangalore, India \\ ${ }^{4}$ Prof.\& Head, Civil Engineering Department, AMC Engineering College Bangalore, India
}

\begin{abstract}
Quantification of short duration high intensity rainfall is generally done using IDF (Intensity-Duration-Frequency) curves, based on historic rainfall data of significant years. Due to non-availability of short duration rainfall data, an attempt is made to derive short duration empirical reduction formula to understand urban hydrology. Bangalore is a rapidly growing city in terms of population and intense urban growth. Today about 70 per cent of the 262 water tanks in 1961 in Bangalore have disappeared leading to surface flooding. Daily rainfall data of5 stations for the years 1998 to 2011 collected from Indian Meteorological Department (IMD) were used in the study. The missing rainfall data, during this period was interpolated by Airthematic_mean method. The IMD empirical reduction formula was used to estimate the short duration rainfall. The rainfall depth for various return periods were predicted using different probability distributions and analyzed. The Chi-Square goodness of fit was used, to arrive at the best statistical distribution among Normal, Log-Normal, Gumbel and Pearson. Chi-Square test showed that lognormal is the best probability distribution for the 5 stations considered. The IDF curves were plotted for short duration rainfall of $5,10,15,30,60,120,720$ and 1440 minutes for a return period of 2, 3, 5, 10, 25, 50, 100 and 200 years for stations with peak rainfall values. The use of IDF curves becomes cumbersome; hence a generalized empirical relationship was developed for the Study Area Suryanagara - Urban Bangalore, through method of least squares.
\end{abstract}

Keywords: Sub-watersheds-Hydrological studies-IDF Curves, Runoff models.

\section{INTRODUCTION}

With the nonlinear interactions between rainfall and runoff processes as described by various urban runoff models, synthetic design storms are required for the estimation of the complete runoff hydrographs for urban drainage design surface and groundwater management purposes. Many frameworks have been conceived in different countries for the computation of design storms (Marsalek and Watt, 1984), with varying shapes, storm durations, time to peak, maximum intensity and total volume of rainfall; however, none matches every situation, forcing hydrologists to perform assessment processes before using a design-storm model at a new site (Peyron, 2001). Peyron et al. (2005) proposed a procedure to systematically evaluate design storms models for specific locations. First, the targeted design storms for different return periods, based on rainfall data from Intensity-Duration-Frequency (IDF) curves, were constructed. Then, these synthetic hyetographs were used as input in the model to obtain the respective runoff values (peak flows and volumes). Thus, the runoff properties estimated from the design storms were compared to those values obtained from observed historical storms to assess the accuracy of different design storm models. Based on this approach, the best design storm can be selected for the design of urban drainage systems and groundwater recharge structures.
Keeping the above aspects in view, Suryanagar sub watershed of Urban Bangalore is taken up for hydrological studies. These studies are concerned about water conservation, storage and management with the motto of recharging groundwater.

\section{STUDY AREA}

The study area is located between Latitude $12^{\circ} 47^{\prime} 32^{\prime \prime} \mathrm{N}$ and Longitude $77^{\circ} 41^{\prime} 59^{\prime \prime} \mathrm{E}$ as shown in figure .1 The study area covers an area of $172.42 \mathrm{~km}^{2}$ and attains maximum elevation $950 \mathrm{~m}$ and minimum elevation of $880 \mathrm{~m}$. Suryanagara Township is situated on the Anekal main road, Chandapura near by cities Benahalii, Attibele, Bangalore. Suryanagara located at distance of $25 \mathrm{~km}$ from Bangalore. physiography of the area is characterized by undulating topography with pediplains, pediment and valley fills. The mean annual total rainfall is about $920 \mathrm{~mm}$ with about 60 rainy days a year over the last ten years.. The summer temperature ranges from $17^{\circ} \mathrm{C}$ to $36^{\circ} \mathrm{C}$, while the winter temperature ranges from $12^{\circ} \mathrm{C}$ to $25^{\circ} \mathrm{C}$. Thus, Bangalore enjoys a salubrious climate all round the year.

The area of the watershed is obtained from delineating the toposheets covering $57 \mathrm{H} / 9$ and $57 \mathrm{H} / 10$ of 1:50000 scale by using ARC GIS software. The area of the watershed is found to be $172.42 \mathrm{~km} 2$ 


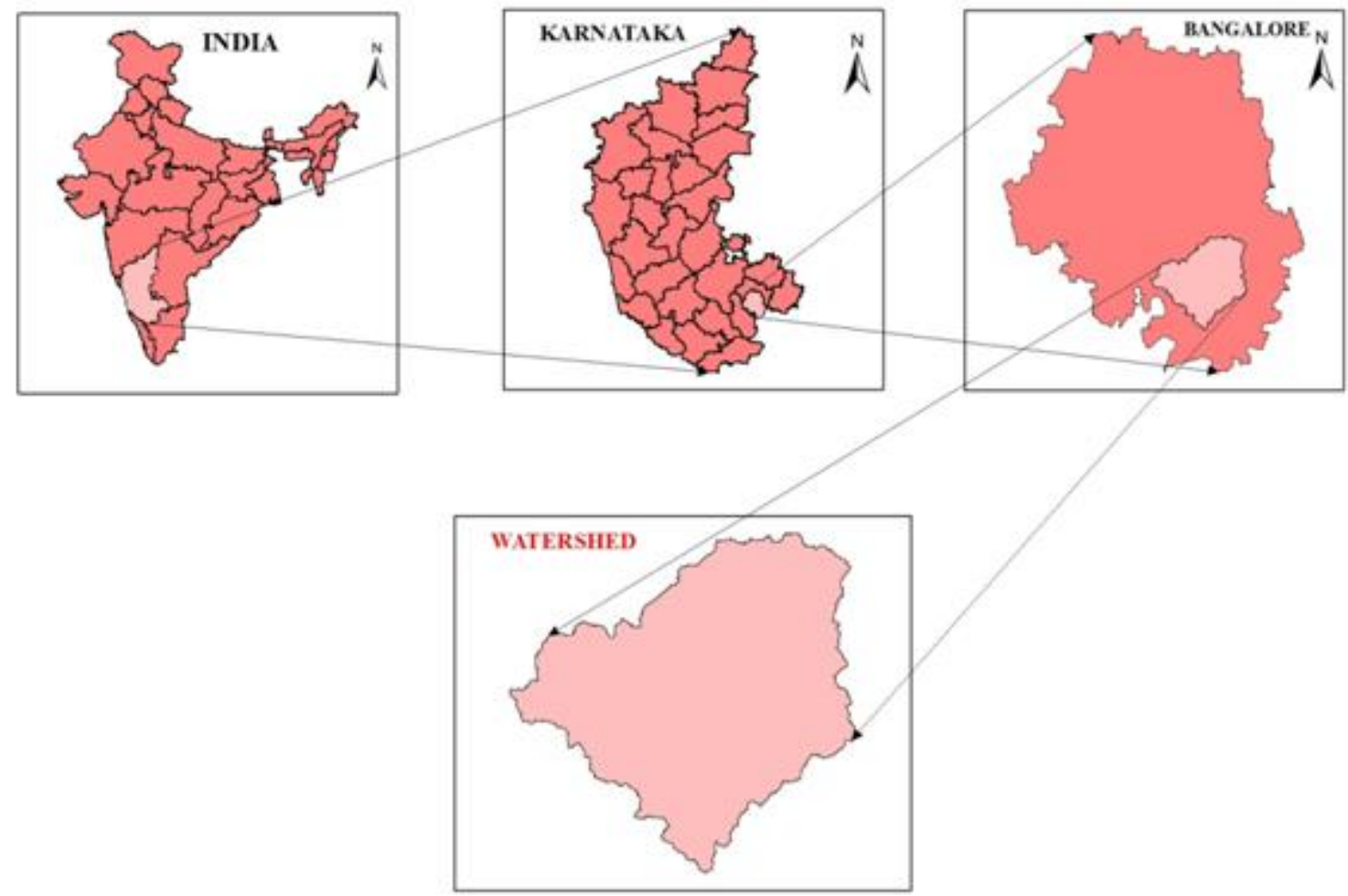

Fig.1: Location Map of Study Area

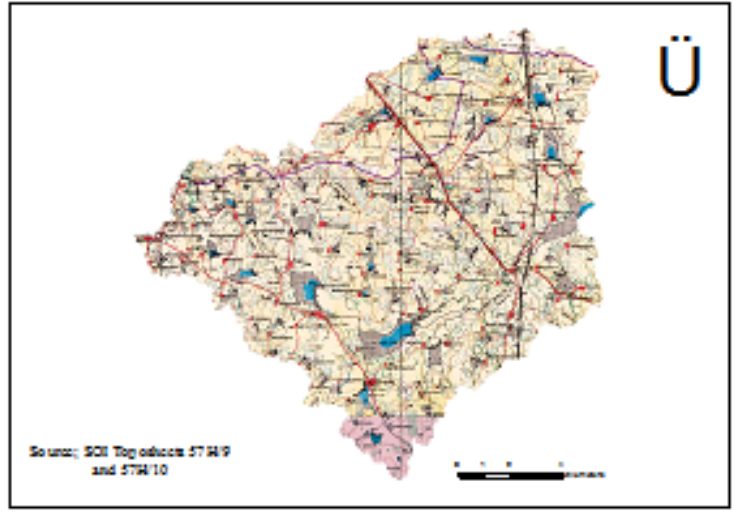

Map of Study area- Suryanagar (Source : SOI Toposheet )

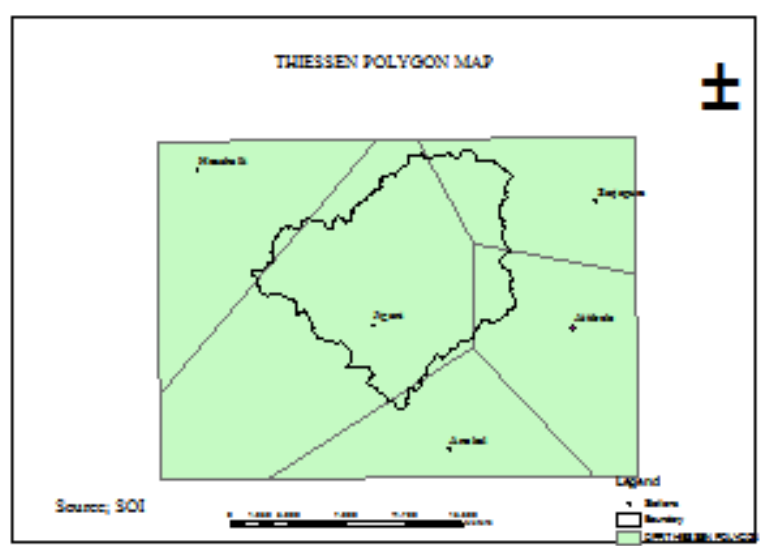

Thiessen polygon map showing rain gauge stations

\section{INTENSITY-DURATION-FREQUENCY-}

\section{CURVES}

IDF stands for Intensity-Duration-Frequency. Rainfall intensity is defined as the ratio of the total amount of rain (rainfall depth) falling during a given period to the duration of the period It is expressed in depth units per unit time, usually as $\mathrm{mm}$ per hour $(\mathrm{mm} / \mathrm{h})$. The period of time over which rainfall is measured is called duration. The number of times, during a specified period of years, that precipitation of a certain magnitude or greater occurs or will occur at a station is called frequency. (FAO, 2012). The IDFrelationships give an idea about the frequency or return period of a mean rainfall intensity or rainfall volume that can be expected within a certain period, i.e. the storm duration. In this sense the storm duration is an artificial parameter that can comprise any part of a rainfall event. (IDFCURVE, 2012)

\section{FREQUENCY \\ ANALYSIS \\ USING \\ FREQUENCY FACTOR}

The magnitude of $\mathrm{x}_{\mathrm{T}}$ of a hydrologic event may be represented as the mean $\mu$ plus the departure $x_{T}$ of the variate from the $\Delta$ mean i.e., $\mathrm{x}_{\mathrm{T}}=\mu+\Delta \mathrm{x}_{\mathrm{T}}$ (Chow et al, 1988). The departure may be taken as equal to the product of $\sigma$ and a frequency factor $\mathrm{K}_{\mathrm{T}}$ are functions of the return period and the type of distribution to be used in the analysis. The above equation may be expressed as $x_{T}=\mu+k_{T} \sigma_{\text {which }}$ may be approximated 
by $x_{T}=\bar{x}+k_{T} s$. (Chow et al, 1988). In the event the variable analysed is $y=\operatorname{In}(x)$, then the same method is applied to the statistics for the logarithms of the data using $y_{T}=\bar{y}+k_{T} s_{y}$ and the required value of $x_{T}$ is foundby taking the antilog of $y_{T}$ (Chow et al, 1988). Short duration rainfall using IMD for Hosahalli raingauge station is tabulated in Table 1

Table 1: Short duration rainfall by using IMD empirical formula for Hosahalli station

\begin{tabular}{|c|c|c|c|c|c|c|c|c|c|}
\hline Year & $\begin{array}{l}\text { Rainfall } \\
(\mathrm{mm})\end{array}$ & \multicolumn{8}{|c|}{$P_{t}=P_{24}\left(\frac{t}{24}\right)^{\frac{1}{3}}$ in mm where, time $t$ is in hours } \\
\hline \multicolumn{2}{|c|}{ Duration in Minutes } & 5 & 10 & 15 & 30 & 60 & 120 & 720 & 1440 \\
\hline 1998 & 82 & 12.42 & 15.64 & 17.91 & 22.56 & 28.43 & 35.82 & 65.08 & 82.00 \\
\hline 1999 & 80.4 & 12.17 & 15.34 & 17.56 & 22.12 & 27.87 & 35.12 & 63.81 & 80.40 \\
\hline 2000 & 120.4 & 18.23 & 22.97 & 26.29 & 33.13 & 41.74 & 52.59 & 95.56 & 120.40 \\
\hline 2001 & 112 & 16.96 & 21.37 & 24.46 & 30.82 & 38.83 & 48.92 & 88.89 & 112.00 \\
\hline 2002 & 25 & 3.79 & 4.77 & 5.46 & 6.88 & 8.67 & 10.92 & 19.84 & 25.00 \\
\hline 2003 & 47 & 7.12 & 8.97 & 10.26 & 12.93 & 16.29 & 20.53 & 37.30 & 47.00 \\
\hline 2004 & 76.8 & 11.63 & 14.65 & 16.77 & 21.13 & 26.63 & 33.55 & 60.96 & 76.80 \\
\hline 2005 & 68.4 & 10.36 & 13.05 & 14.94 & 18.82 & 23.71 & 29.88 & 54.29 & 68.40 \\
\hline 2006 & 45.4 & 6.87 & 8.66 & 9.92 & 12.49 & 15.74 & 19.83 & 36.03 & 45.40 \\
\hline 2007 & 53.4 & 8.09 & 10.19 & 11.66 & 14.69 & 18.51 & 23.32 & 42.38 & 53.40 \\
\hline 2008 & 70.1 & 10.62 & 13.37 & 15.31 & 19.29 & 24.30 & 30.62 & 55.64 & 70.10 \\
\hline 2009 & 95.2 & 14.42 & 18.16 & 20.79 & 26.20 & 33.00 & 41.58 & 75.56 & 95.20 \\
\hline 2010 & 56.2 & 8.51 & 10.72 & 12.27 & 15.46 & 19.48 & 24.55 & 44.61 & 56.20 \\
\hline 2011 & 68.1 & 10.31 & 12.99 & 14.87 & 18.74 & 23.61 & 29.75 & 54.05 & 68.10 \\
\hline
\end{tabular}

\section{NORMAL DISTRIBUTION}

Normal probability distribution, also called Gaussian distribution refers to a family of distributions that are bell shaped. The PDF for a normal random variable $\mathrm{x}$ is

$f(x)=\frac{1}{\sigma \sqrt{2 \pi}} \exp \left[-\frac{1}{2}\left(\frac{x-\mu}{\sigma}\right)^{2}\right](\sigma>0)$

Where exp is the exponential function with base $e=2.718$. $\mu$ is the mean and $\sigma$ the standard deviation. $1 /(\sigma \sqrt{ }(2 \pi))$ is a constant factor that makes the area under the curve of $f(x)$ from $-\infty$ to $\infty$ equal to 1 . The curve of $f(x)$ is symmetric with respect to $x=\mu$ because the exponent is quadratic. Hence for $\mu=0$ it is symmetric with respect to the $y$-axis $x$ $=0$. The frequency factor for normal distribution is given by $k_{T}=\frac{x_{T}-\mu}{\sigma}$. This is same as the standard normal variate $\mathrm{z}$ i.e., frequency factor $k_{T}=\mathrm{z}$. Figure 2 shows the variation of Normal distribution for different durations and results are tabulated in Table2. 


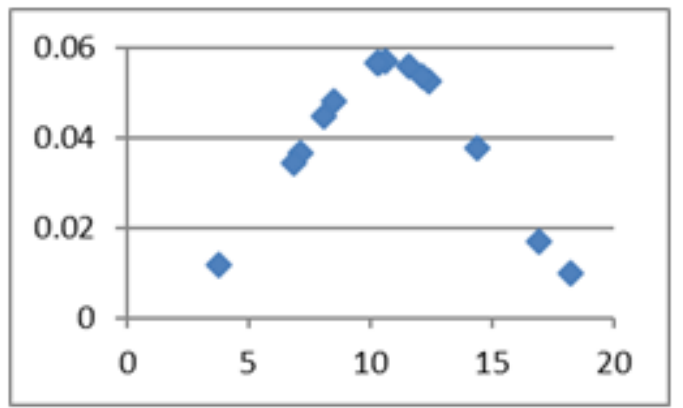

Normal for $5 \mathrm{Min}$

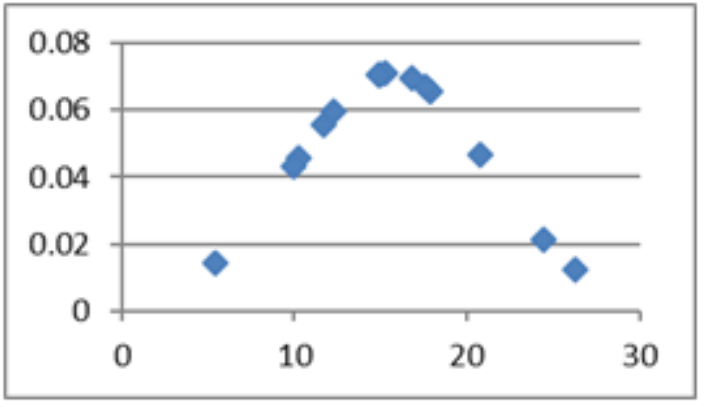

Normal for $15 \mathrm{Min}$

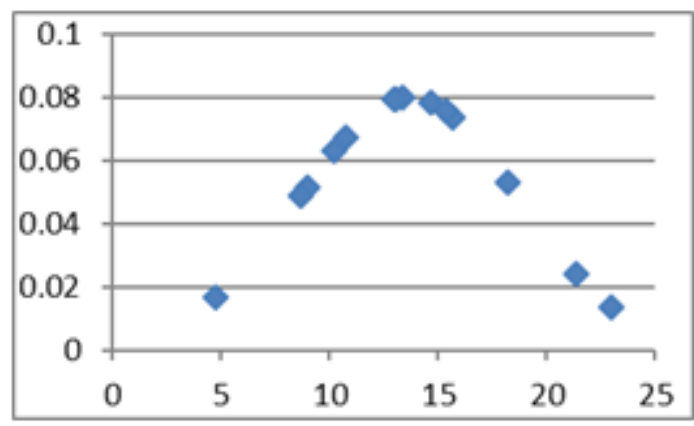

Normal for 10 Min

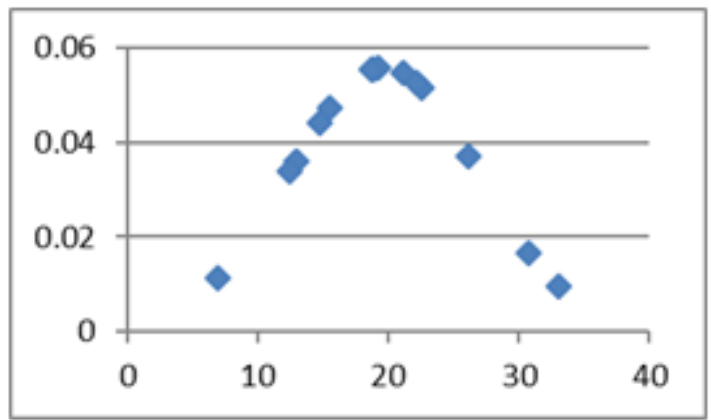

Normal for 30 Min

Fig.2: Variation of Normal Distribution For Different Durations

Table 2: Estimation of maximum rainfall intensity for various return period by normal distribution for Hosahalli station

\begin{tabular}{|c|c|c|c|c|c|c|c|c|c|c|}
\hline $\begin{array}{l}\text { NORMA } \\
\text { L } \\
\text { DISTRI }\end{array}$ & \multicolumn{2}{|c|}{ Return period $\mathrm{T}$} & \multicolumn{2}{|l|}{2} & \multicolumn{2}{|l|}{3} & \multicolumn{2}{|l|}{5} & \multicolumn{2}{|l|}{10} \\
\hline $\begin{array}{l}\text { Duration } \\
\text { in } \\
\text { minutes }\end{array}$ & Mean & $\begin{array}{l}\text { Standard } \\
\text { Deviatio } \\
\mathrm{n}\end{array}$ & $\begin{array}{l}\text { Rainfall } \\
\text { Depth(m } \\
\text { m) }\end{array}$ & $\begin{array}{l}\text { Rainfal } \\
1 \\
(\mathrm{~mm} / \mathrm{hr} \\
)\end{array}$ & $\begin{array}{l}\text { Rainfall } \\
\text { Depth(m } \\
\text { m) }\end{array}$ & $\begin{array}{l}\text { Rainfal } \\
1 \\
(\mathrm{~mm} / \mathrm{hr} \\
)\end{array}$ & $\begin{array}{l}\text { Rainfall } \\
\text { Depth(m } \\
\text { m) }\end{array}$ & $\begin{array}{l}\text { Rainfal } \\
1 \\
(\mathrm{~mm} / \mathrm{hr} \\
)\end{array}$ & $\begin{array}{l}\text { Rainfall } \\
\text { Depth(m } \\
\text { m) }\end{array}$ & $\begin{array}{l}\text { Rainfal } \\
1 \\
(\mathrm{~mm} / \mathrm{hr}\end{array}$ \\
\hline 5 & 10.82 & 3.95 & 13.55 & 162.62 & 13.78 & 165.32 & 13.93 & 167.20 & 14.04 & 168.52 \\
\hline 10 & 13.63 & 4.98 & 17.07 & 102.44 & 17.36 & 104.15 & 17.55 & 105.33 & 17.69 & 106.16 \\
\hline 15 & 15.61 & 5.69 & 19.54 & 78.18 & 19.87 & 79.48 & 20.10 & 80.38 & 20.25 & 81.01 \\
\hline 30 & 19.66 & 7.17 & 24.62 & 49.24 & 25.03 & 50.05 & 25.31 & 50.63 & 25.51 & 51.02 \\
\hline 60 & 24.77 & 9.04 & 31.02 & 31.02 & 31.54 & 31.54 & 31.89 & 31.89 & 32.15 & 32.15 \\
\hline 120 & 31.21 & 11.39 & 39.09 & 19.54 & 39.74 & 19.87 & 40.19 & 20.09 & 40.50 & 20.25 \\
\hline 720 & 56.72 & 20.7 & 71.03 & 5.92 & 72.22 & 6.02 & 73.03 & 6.09 & 73.61 & 6.13 \\
\hline 1440 & 71.46 & 26.08 & 89.49 & 3.73 & 90.98 & 3.79 & 92.01 & 3.83 & 92.74 & 3.86 \\
\hline $\begin{array}{l}\text { NORMA } \\
\text { L } \\
\text { DISTRI } \\
\text { BUTION }\end{array}$ & \multicolumn{2}{|c|}{ Return period $\mathrm{T}$} & \multicolumn{2}{|l|}{25} & \multicolumn{2}{|l|}{50} & \multicolumn{2}{|l|}{100} & \multicolumn{2}{|l|}{200} \\
\hline 5 & 10.82 & 3.95 & 14.10 & 169.26 & 14.12 & 169.49 & 14.13 & 169.60 & 14.13 & 169.61 \\
\hline 10 & 13.63 & 4.98 & 17.77 & 106.62 & 17.80 & 106.77 & 17.81 & 106.84 & 17.81 & 106.85 \\
\hline 15 & 15.61 & 5.69 & 20.34 & 81.36 & 20.37 & 81.48 & 20.38 & 81.53 & 20.38 & 81.54 \\
\hline 30 & 19.66 & 7.17 & 25.62 & 51.24 & 25.66 & 51.31 & 25.67 & 51.35 & 25.68 & 51.36 \\
\hline 60 & 24.77 & 9.04 & 32.29 & 32.29 & 32.33 & 32.33 & 32.35 & 32.35 & 32.35 & 32.35 \\
\hline 120 & 31.21 & 11.39 & 40.68 & 20.34 & 40.74 & 20.37 & 40.77 & 20.38 & 40.77 & 20.38 \\
\hline 720 & 56.72 & 20.7 & 73.93 & 6.16 & 74.03 & 6.17 & 74.09 & 6.17 & 74.09 & 6.17 \\
\hline 1440 & 71.46 & 26.08 & 93.14 & 3.88 & 93.27 & 3.89 & 93.34 & 3.89 & 93.34 & 3.89 \\
\hline
\end{tabular}


The scope of this study was to develop IDF curve and to derive IDF empirical formulae for the 5 stations considered for the study area - Suryanagara Bangalore, so that the estimation of rainfall depth and intensity for any standard duration and return period in the study area considered can be obtained with minimum effort. And also to estimate the surface runoff for the study area by using different methods can be obtained with minimum effort.

Daily rainfall data for 14 years i.e., 1998 to 2011 was collected for 5 stations in and around Suryanagara, Bangalore from Indian Meteorological Department (IMD), Government of India. The missing rainfall values were calculated using the airthematic mean method and the IMD empirical reduction formula was used to estimate the short duration rainfall. Using different probability distributions the rainfall depth was found out for different durations and standard return period, and subsequently the rainfall intensity was found out for calculated rainfall depths. The Chi-Square goodness of fit was used to arrive at the best statistical distribution among Normal, Log-Normal, Gumbel and Pearson.IDF curve was plotted for short duration rainfall of $5,10,15,30,60,120,720$ and 1440 minutes for a return period of $2,3,5,10,25,50,100$ and 200 years for station with peak rainfall values. The use of IDF curves becomes cumbersome and hence a generalized empirical relationship was developed through method of least squares.

The daily 24 hour rainfall data for the years 1998 to 2011 was collected from IMD for 5 stations located in and around Suryanagara, Bangalore. The 5 stations are Anekal, Attibele, Jigani, Sarjapura and Hosalli. The missing rainfall values for the years 1998 to 2011 were calculated and tabulated in table 3 .

Table 3: Mean and Standard Deviations of Short Duration Rainfall

\begin{tabular}{|c|c|c|c|c|c|c|}
\hline \multirow{2}{*}{$\begin{array}{l}\text { Duration in } \\
\text { minutes }\end{array}$} & Mean & $\begin{array}{l}\text { Standard } \\
\text { Deviation }\end{array}$ & Mean & $\begin{array}{l}\text { Standard } \\
\text { Deviation }\end{array}$ & Mean & $\begin{array}{l}\text { Standard } \\
\text { Deviation }\end{array}$ \\
\hline & \multicolumn{2}{|c|}{ HOSAHALLI } & \multicolumn{2}{|c|}{ ANEKAL } & \multicolumn{2}{|c|}{ ATTIBELE } \\
\hline 5 & 10.82 & 3.95 & 11.45 & 3.95 & 11.13 & 4.48 \\
\hline 10 & 13.63 & 4.98 & 14.43 & 4.74 & 14.02 & 5.64 \\
\hline 15 & 15.61 & 5.69 & 16.52 & \begin{tabular}{|l|}
5.43 \\
\end{tabular} & 16.05 & 6.46 \\
\hline 30 & 19.66 & 7.17 & 20.81 & 6.84 & 20.22 & 8.14 \\
\hline 60 & 24.77 & 9.04 & 26.22 & 8.62 & 25.48 & 10.25 \\
\hline 120 & 31.21 & 11.39 & 33.04 & 10.86 & 32.10 & 12.92 \\
\hline 720 & 56.72 & 20.7 & 60.03 & 19.74 & 58.33 & 23.48 \\
\hline 1440 & 71.46 & 26.08 & 71.46 & 25.24 & 73.49 & 29.65 \\
\hline
\end{tabular}

\begin{tabular}{|l|l|l|l|l|}
\hline \multirow{2}{*}{$\begin{array}{l}\text { Duration in } \\
\text { minutes }\end{array}$} & Mean & $\begin{array}{l}\text { Standard } \\
\text { Deviation }\end{array}$ & Mean & $\begin{array}{l}\text { Standard } \\
\text { Deviation }\end{array}$ \\
\cline { 2 - 5 } & SARJAPURA & JIGANI & \\
\hline 5 & 9.68 & 2.91 & 15.46 & 6.84 \\
\hline 10 & 12.20 & 3.66 & 19.48 & 8.62 \\
\hline 15 & 13.96 & 4.20 & 22.3 & 9.87 \\
\hline 30 & 17.59 & 5.29 & 28.09 & 12.44 \\
\hline 60 & 22.17 & 6.66 & 35.39 & 15.67 \\
\hline 120 & 27.93 & 8.39 & 44.59 & 19.74 \\
\hline 720 & 50.75 & 15.25 & 81.03 & 35.88 \\
\hline 1440 & 63.94 & 20.73 & 102.09 & 45.2 \\
\hline
\end{tabular}

\section{RAINFALL DEPTH AND INTENSITY}

The short duration rainfall depths were calculated for the years 1998 to 2011 from IMD empirical reduction formula. Then the mean and standard deviations of short durations of $5,10,15,30,60,120,720$ and 1440 minutes were estimated. These estimated mean and standard deviations were used in Normal, Log-Normal, Gumbel and Pearson probability distribution methods to determine the rainfall depths and intensity for standard return periods of 2, 3, 5, $10,25,50,100$ and 200 years for 5 stations. It was found that the rainfall depths increased with the increasing time duration. But the rainfall intensity decreased appreciably with increasing duration. These distributions were subjected to chi-square goodness of fit test to find the best distribution. The table4 shows specimen calculations for Hosahalli station

Table 4: Specimen calculations for Hosahalli station

\begin{tabular}{|c|c|c|c|c|c|c|c|c|c|}
\hline \multirow{2}{*}{$\begin{array}{l}\text { Duratio } \\
\mathrm{n} \quad \text { in } \\
\text { minutes }\end{array}$} & \multirow{2}{*}{$\begin{array}{l}\text { Observe } \\
\mathrm{d} \text { values }\end{array}$} & \multicolumn{2}{|c|}{$\begin{array}{l}\text { NORMAL } \\
\text { DISTRIBUTION }\end{array}$} & \multicolumn{2}{|c|}{$\begin{array}{l}\text { LOG-NORMAL } \\
\text { DISTRIBUTION }\end{array}$} & \multicolumn{2}{|c|}{$\begin{array}{l}\text { GUMBELS } \\
\text { DISTRIBUTION }\end{array}$} & \multicolumn{2}{|c|}{$\begin{array}{lr}\text { PEARSON } & \text { TYPE } \\
\text { III DISTRIBUTION }\end{array}$} \\
\hline & & $\begin{array}{l}\text { Expected } \\
\text { values }\end{array}$ & $\begin{array}{l}\text { Chi- } \\
\text { square }\end{array}$ & $\begin{array}{l}\text { Expected } \\
\text { values }\end{array}$ & $\begin{array}{l}\text { Chi- } \\
\text { square }\end{array}$ & $\begin{array}{l}\text { Expected } \\
\text { values }\end{array}$ & $\begin{array}{l}\text { Chi- } \\
\text { square }\end{array}$ & $\begin{array}{l}\text { Expected } \\
\text { values }\end{array}$ & $\begin{array}{l}\text { Chi- } \\
\text { square }\end{array}$ \\
\hline
\end{tabular}




\begin{tabular}{|l|l|l|l|l|l|l|l|l|l|}
\hline & & & values & & values & & values & values \\
\hline 5 & 10.82 & 13.97 & 0.71 & 13.48 & 0.52 & 17.52 & 2.56 & 16.17 & 1.77 \\
\hline 10 & 13.63 & 17.61 & 0.90 & 16.99 & 0.66 & 22.08 & 3.23 & 20.37 & 2.23 \\
\hline 15 & 15.61 & 20.15 & 1.02 & 19.45 & 0.76 & 25.26 & 3.69 & 23.31 & 2.54 \\
\hline 30 & 19.66 & 25.39 & 1.29 & 24.50 & 0.96 & 31.82 & 4.65 & 29.37 & 3.21 \\
\hline 60 & 24.77 & 31.99 & 1.63 & 30.87 & 1.21 & 40.11 & 5.87 & 37.06 & 4.08 \\
\hline 120 & 31.21 & 40.31 & 2.05 & 38.89 & 1.52 & 50.53 & 7.39 & 46.63 & 5.10 \\
\hline 720 & 56.72 & 73.25 & 3.73 & 70.68 & 2.76 & 91.84 & 13.43 & 84.75 & 9.27 \\
\hline 1440 & 71.46 & 92.29 & 4.70 & 89.05 & 3.47 & 115.71 & 16.92 & 106.77 & 11.68 \\
\hline
\end{tabular}

\section{IDF CURVE}

It was found from chi-square test that log-normal distribution gave the best results with minimum deviations from the observed values. Hence the IDF curve was plotted from log-normal values for each station considered. The IDF curve is plotted with duration in minutes on the abscissa and rainfall intensity in $\mathrm{mm} / \mathrm{hr}$ on the ordinate for standard return periods.

Figure 3 represents the rainfall IDF curves for five stations in the study area i.e., rainfall intensity-duration-frequency curve for short durations of $5,10,15,30,60,120,720$ and
1440 minutes and return periods of $2,3,5,10,25,50,100$ and 200 years for Log-normal distribution. The use of IDF curves becomes more cumbersome and hence a generalized empirical relationship of the form $\mathrm{i}=\mathrm{x} *\left(\mathrm{t}_{\mathrm{d}}\right)^{-\mathrm{y}}$ was developed for each station, for the various return period considered. Rainfall IDF empirical equation constant $\mathrm{x}$ and $y$ were calculated for different return period by the method of least-squares. IDF empirical equation was formed by putting the value of $\mathrm{x}$ and $\mathrm{y}$ in the mentioned equation format for each return period separately. Table 5 gives the empirical constant $\mathrm{x}$ for 5 stations for the return periods considered.

Table 5: Empirical constant $x$ for 5 stations for different return periods

\begin{tabular}{|l|l|l|l|l|l|l|l|l|}
\hline Station & Return Periods \\
\hline & 2 & 3 & 5 & 10 & 25 & 50 & 100 & 200 \\
\hline Hosahalli & 465 & 474 & 481 & 486 & 489 & 489 & 490 & 490 \\
\hline Anekal & 478 & 487 & 493 & 498 & 500 & 501 & 502 & 502 \\
\hline Attibele & 483 & 494 & 502 & 507 & 510 & 511 & 512 & 512 \\
\hline Sarjapura & 408 & 415 & 420 & 424 & 426 & 426 & 427 & 427 \\
\hline Jigani & 678 & 695 & 707 & 715 & 720 & 721 & 722 & 722 \\
\hline
\end{tabular}

It is seen that the empirical constant y remains constant for all return period and for all stations with a value of 0.6667 or $2 / 3$. The empirical constant $\mathbf{x}$ varies at lower return periods and tends to become constant with higher return periods. These IDF empirical equations will help to estimate the rainfall intensity for any specific return period in Urban in a short time and more easily for the locations considered.

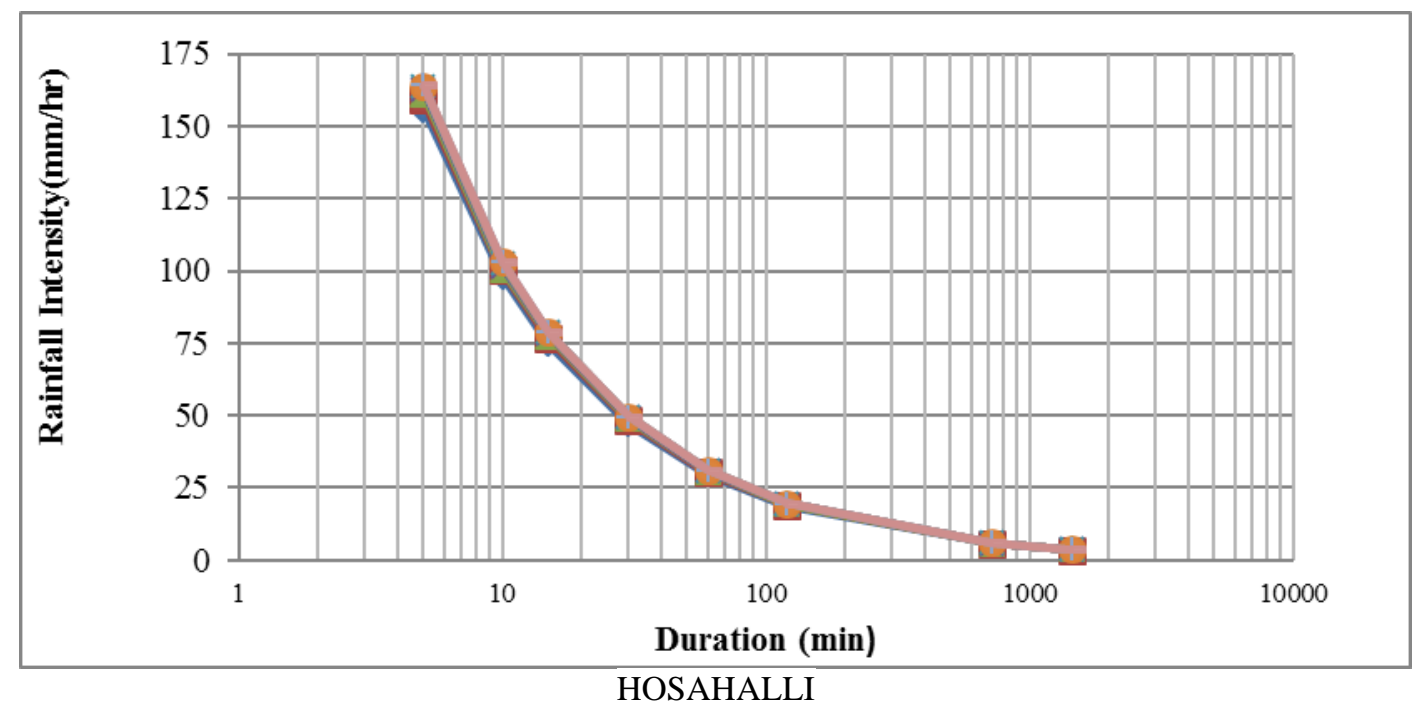




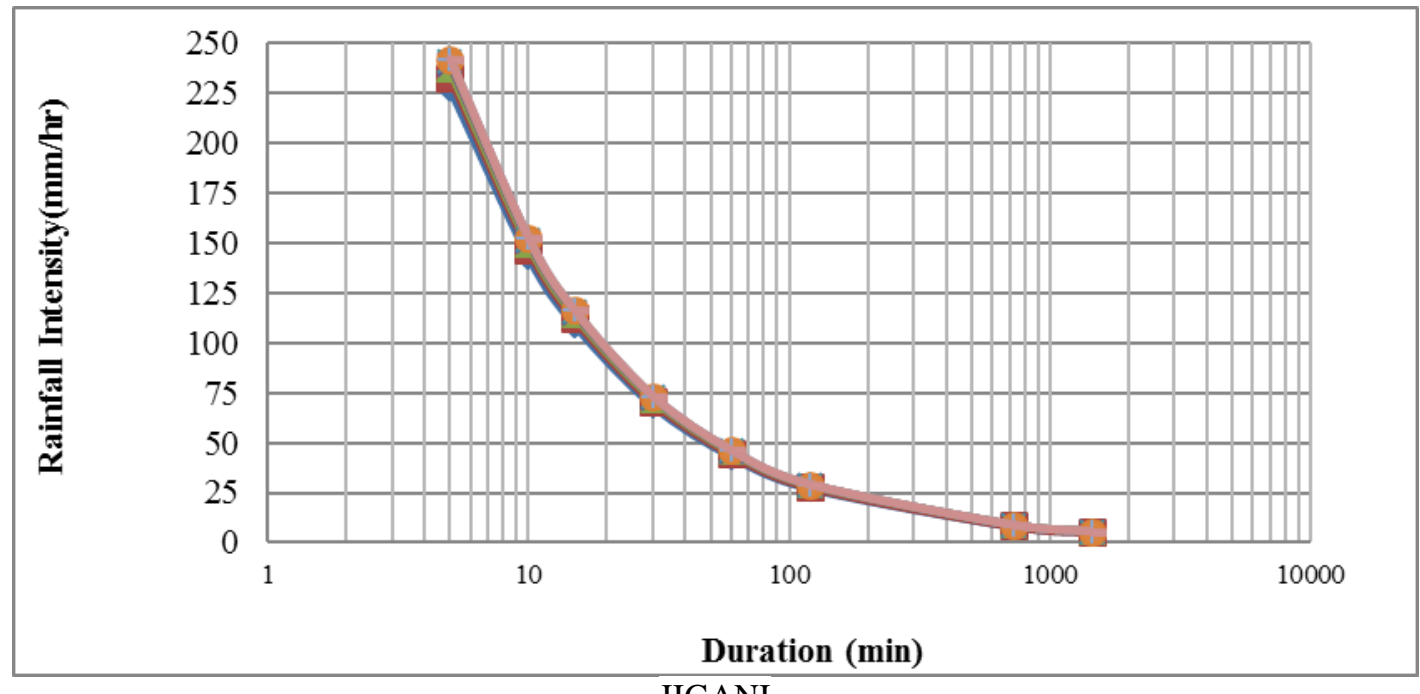

JIGANI

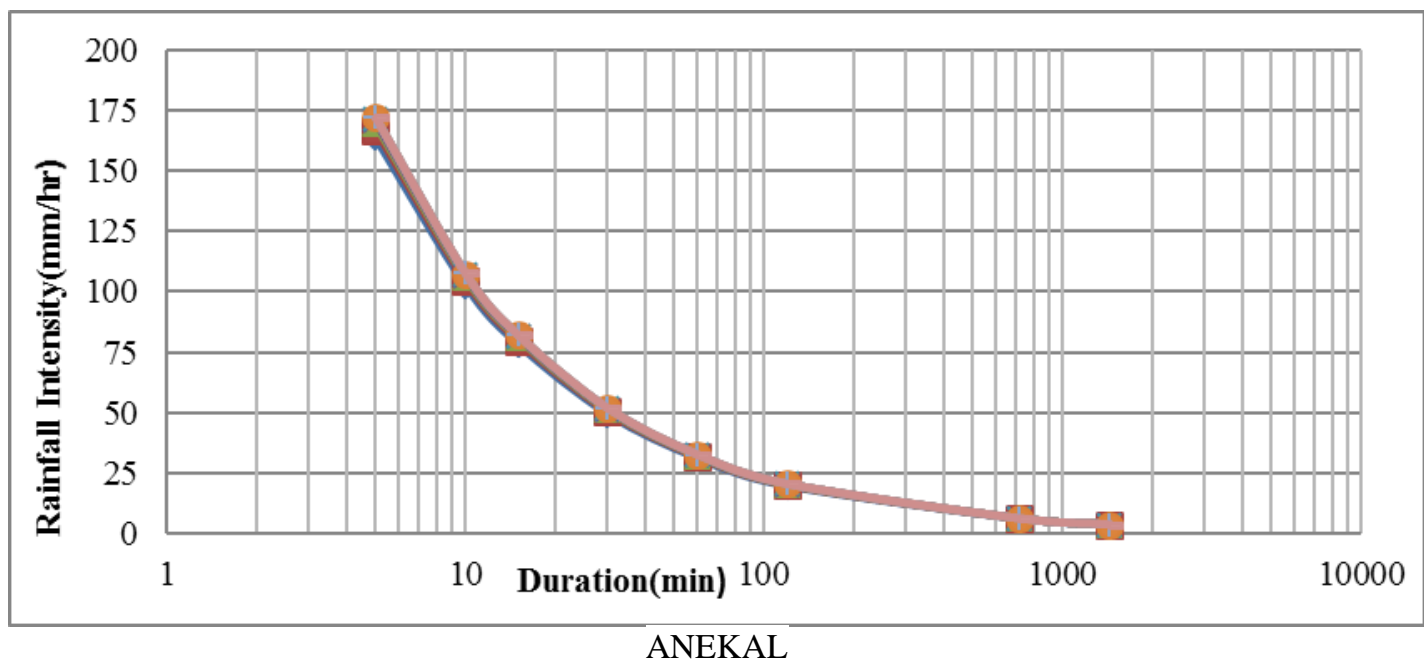

Fig. 3: IF Curves for Rain Gauge Stations

\section{SOIL CONSERVATION SERVICE (SCS)} CURVE NUMBER MODEL

The SCS developed an index, which is called as the runoff Curve Number $(\mathrm{CN})$ to represent the combined hydrologic effect of soil, land use, agriculture treatment class, hydrologic condition and antecedent soil moisture. These factors can be accessed from soil surveys, site investigations and land use maps, while using the SCS hydrologic models for design. Fig 4, 5 \& 6 show the Curve Number Map generated, rainfall runoff relationship and CWC Hydrograph for the study area. Weighted curve number and runoff estimation is tabulated in Table $6 \& 7$. 


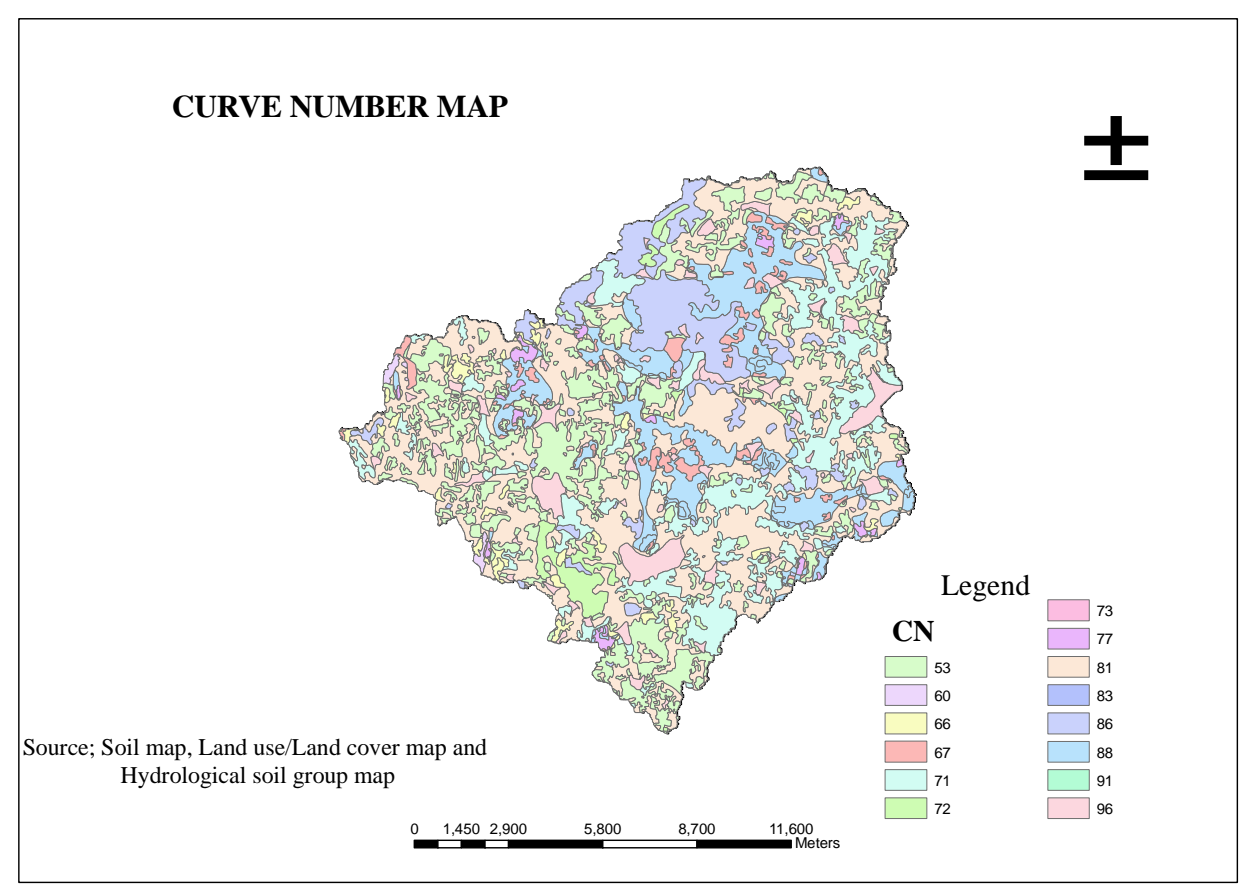

Fig 4: Curve Number Map

Table 6 Weighted Curve Number

\begin{tabular}{|l|l|l|l|l|}
\hline Watershed & Area $($ Sq km) & CNI & CNII & CNIII \\
\hline SURYANAGARA & 172.42 & 58.13 & 76 & 88.12 \\
\hline
\end{tabular}

Table 7: Runoff Estimated for Surynagara Catchment

\begin{tabular}{|l|l|l|}
\hline Year & Rainfall $(\mathrm{mm})$ & Runoff $(\mathrm{mm})$ \\
\hline 1998 & 1387.3 & 498.81 \\
\hline 1999 & 1518.4 & 560.48 \\
\hline 2000 & 1374 & 427.69 \\
\hline 2001 & 886.6 & 313.96 \\
\hline 2002 & 669.3 & 227.69 \\
\hline 2003 & 617.8 & 58.28 \\
\hline 2004 & 1111.2 & 251.24 \\
\hline 2005 & 1204.2 & 352.60 \\
\hline 2006 & 417.2 & 48.66 \\
\hline 2007 & 1076.6 & 259.70 \\
\hline 2008 & 1079.8 & 329.57 \\
\hline 2009 & 1196.5 & 390.71 \\
\hline 2010 & 898.8 & 209.69 \\
\hline 2011 & 903.2 & 240.18 \\
\hline 2012 & 584.4 & 141.54 \\
\hline Average & 995.02 & 287.39 \\
\hline Maximum & 1518.4 & 560.48 \\
\hline Minimum & 417.2 & 48.66 \\
\hline
\end{tabular}




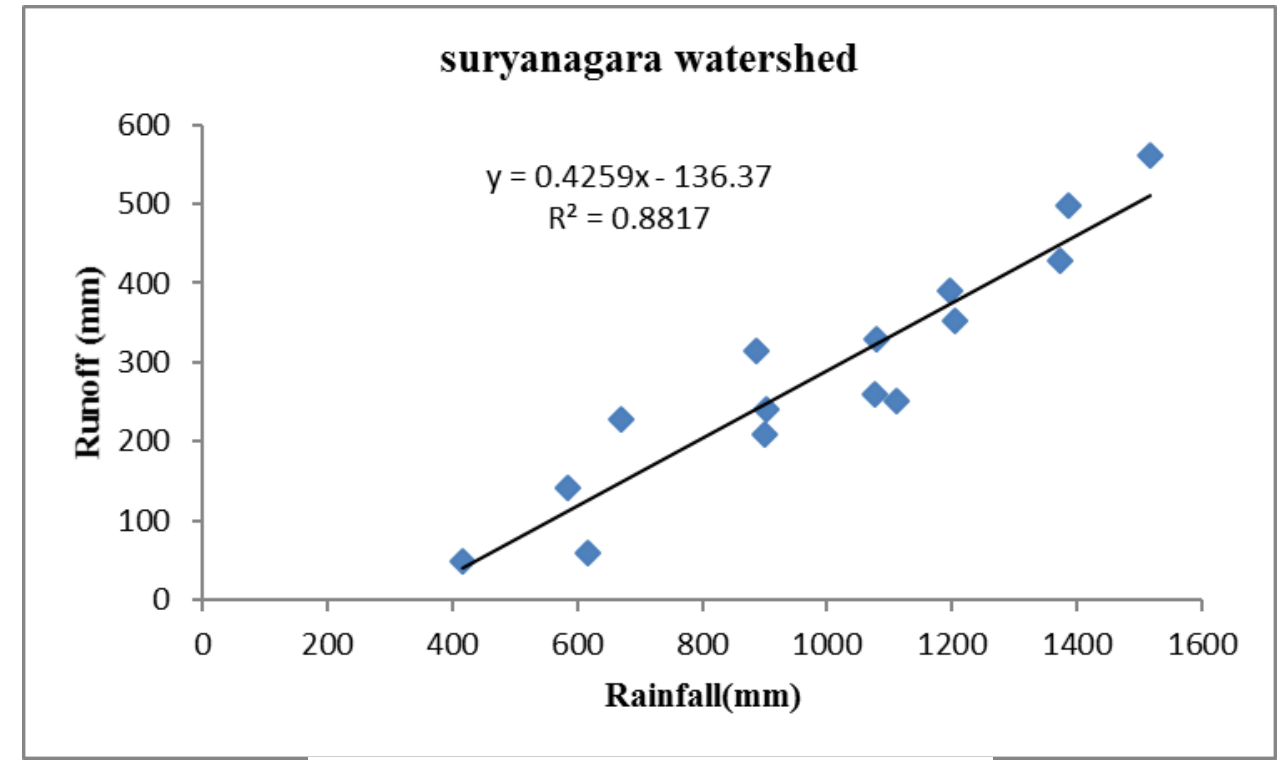

Fig 5: Rainfall-Runoff relationship of watershed.

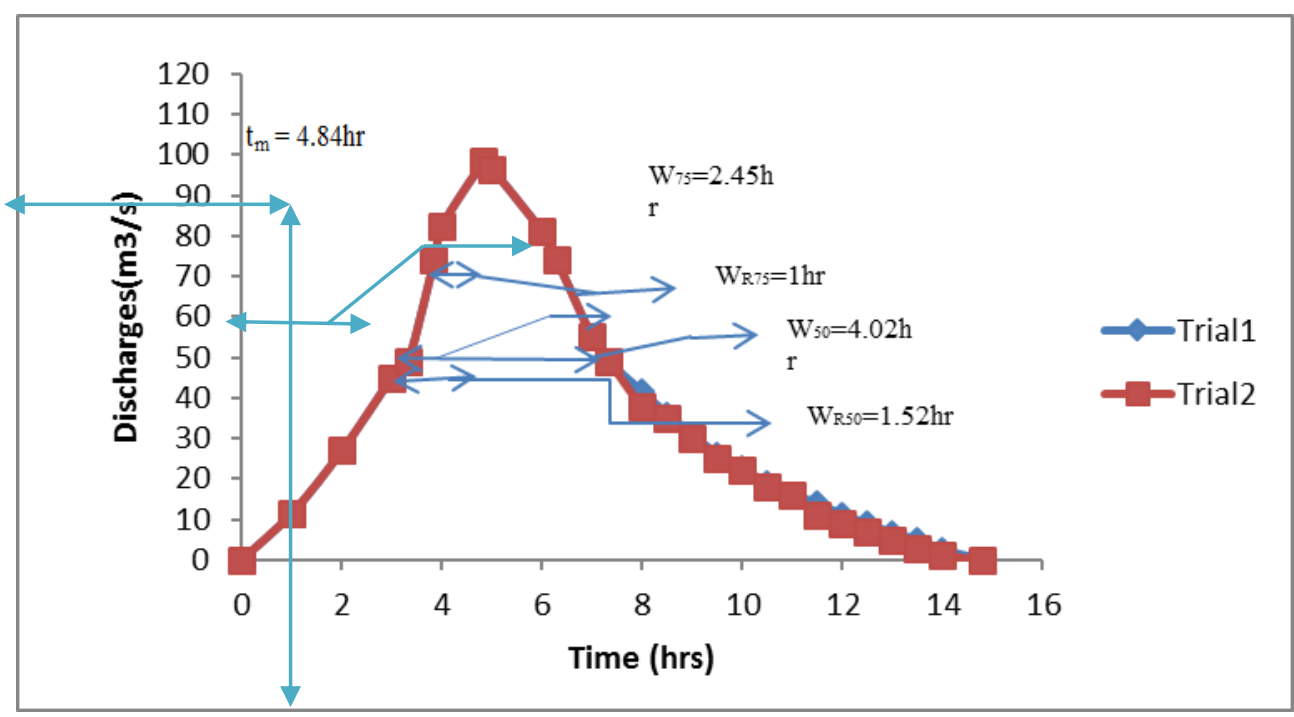

Fig 6: CWC Unit Hydrograph for the Suryanagara watershed

\section{CONCLUSION}

- Among the various available probability distribution functions Log_ Normal distribution had the best approximation of rainfall intensity for various return periods.

- Study showed that $\mathrm{i}=\mathrm{x} *\left(\mathrm{t}_{\mathrm{d}}\right)^{-\mathrm{y}}$ was the best form of IDF empirical equation for Suryanagara, Bangalore.

- These IDF equations will help to estimate the rainfall intensity for any specific return period in Suryanagara, Bangalore in a short time and more easily.

- The runoff models developed in this study (ie..Rational, SCS- CN model and Unit hydrograph method) is useful for designing surface drain network for recharging ground water and for surface water management.

\section{REFERENCES}

[1] Chow V.T., D.R. Maidment and L.W.Mays, 1988, "Applied Hydrology", McGraw- Hill, Chapter 10 Probability, Risk and Uncertainty Analysis for Hydrologic and Hydraulic Design: 361 - 398.

[2] Food and Agriculture Organization, (2012), Rainfall Runoff Analysis, Rainfall Characteristics, http://www.fao.org/docrep/U3160E/u3160e05.htm

[3] Marsalek, J. and Watt, W.E. (1984) Design Storms for Urban Drainage Design. Canadian Journal of Civil Engineering 11(3), 574-584.

[4] Peyron, N. (2001) Design Storms for Urban Runoff Estimation. Project Report, McGill University, Montréal, Canada.

[5] Peyron, N., Nguyen, V.T.V. and Rivard, G. (2005) Un modele optimal de pluie de projet pour la conception des reseaux de drainage urbain. Annales du batiment et des travaux publics, 35-42. 